\title{
Development of physiotherapy through the history and education in Bosnia and Herzegovina
}

\author{
Amra Mačak Hadžiomerović* ${ }^{*}$ Amila Jaganjac, Dijana Avdić, Samir Bojičić, Bakir Katana, Muris
} Pecar, Fuad Julardžija

Faculty of Health Studies, University of Sarajevo, Bolnička 25, Sarajevo, Bosnia and Herzegovina

\begin{abstract}
In the study, the development of physiotherapy was described through the history and education in Bosnia and Herzegovina $(\mathrm{BiH})$ with the special review on the significance of physiotherapy as a health-care discipline and the display of its development to the academic level of education in $\mathrm{BiH}$.
\end{abstract}

Key words: Physiotherapy; history; education

\section{THE DEVELOPMENT OF PHYSIOTHERAPY IN BOSNIA AND HERZEGOVINA AND IN THE WORLD}

The history of physiotherapy started from the moment when physiotherapy was began to be defined as a separate health-care profession at the beginning of the $20^{\text {th }}$ century (1). Physiotherapy although being a younger branch of health care had spread its roots far away into the past, even to the period of Roman rule, Ottomans, and AustroHungarian dominance. In the period of Roman Empire, the springs of thermal waters were known and they were used as the sanatoriums for various diseases, especially for the treatment of rheumatic disease and various kinds of disabilities. The evidences of existence and usage of thermal springs were

\footnotetext{
*Corresponding author: Prof. Dr. Amra Mačak

Hadžiomerović, Faculty of Health Studies, University of

Sarajevo, Bolnička 25, Sarajevo, Bosnia and Herzegovina.

E-mail: amra.macak-h@fzs.unsa.ba
}

Submitted: 12 October 2019/Accepted: 30 December 2019 found in Fojnica, Srebrenica, and Ilidža - Sarajevo. For Ilidža, there is even a written document from the period of Roman Empire where thermal waters were used, for which the witnesses are the remains of Roman buildings and spas, as well as findings of Roman money discovered in 1893 during the building of the hotel in the same location. According to those findings, the spa was built in the $1^{\text {st }}$ century, and it was used until the $2^{\text {nd }}$ century. Based on a stone plate found in 1937, it could be concluded that the place was called Aqua Staneclorum (2-4).

With the fall of Medieval Bosnian kingdom under the Ottoman rule (1464) the changes of customs and cultural values occur, hamams (Turkish baths) and public baths were began to be built. First traces of activities that resemble the precursors of modern physiotherapy in Bosnia and Herzegovina $(\mathrm{BiH})$ originate from this period, because Ottomans practiced various forms of body peeling and massage in hamams, those practices were also transmitted to local population. During the five centuries of Ottoman rule in $\mathrm{BiH}$ not much more has changed that could be considered relevant for the further development of physiotherapy. (5). 
All until the $19^{\text {th }}$ century in $\mathrm{BiH}$, there was a small number of educated medical personnel, and the treatments were done by quacks, physicians healers, physicians surgeons, priests, and barbers, who qualified to restore broken bones, pull teeth, and do less complicated surgical operations. First educated medical personnel were Franciscans and Jews that were educated on the medical universities in Italy, Austria, and Hungary $(4,6,7)$.

The health-care services in $\mathrm{BiH}$ experienced its prosperity during the Austro-Hungarian rule (7). During that period, the first chemical analysis of thermomineral water in the area of Ilidža was done, which was achieved by prof. dr. Ernst Ludwig in his study, sulfur spa Ilidža by Sarajevo, comparing the quality of Ilidža water to the most famous world spas (Figures 1,2.) (8).

During the period from 1892 to 1893 , arranging the sanatorium began and then the new bathing place was built with its 14 bathtubs and two pools, as well as three accommodating buildings. From then till now, this water has had constant structure and temperature $(3,9)$. Bathing places were used by all who had enough means to pay their services, whether they were locals or those that came from other parts of monarchy or Europe, which sped the awareness of the need of such sanatoriums and the understanding of the significance of the physiotherapy procedures that were offered in the sanatoriums (5).

After the end of the First World War, there was a great number of war invalids in $\mathrm{BiH}$, and especially

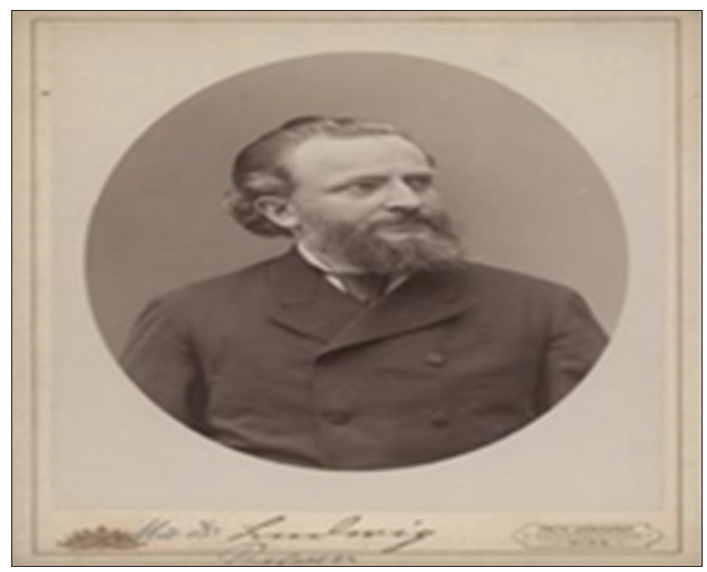

FIGURE 1. Ludwig Ernst. Available at: http://www.biographien. ac.at/oebl/oebl_L/Ludwig_Ernst_1842_1915.xml. people with amputated limbs. Such a situation stipulated the need for founding special institutions for tending and care, as well as the institutions for making the prosthesis. It is known that in such institutions, besides offering the care, certain therapeutic exercises were held by usually not enough qualified people, and the prosthesis from the wood were made by invalids themselves. By the end of the Second World War, when there was a great number of people with disabilities as the consequences of the war, institutions for the care of invalids were organized in quite unfavorable conditions, as well as the institutions for disabled persons (3).

During that period, physiotherapy as a health-care branch did not exist in $\mathrm{BiH}$, but it was the component of the treatment in the context of almost all specialties. Then, the gradual recovery of the country began together with establishing the communication with developed countries in the world, the countries where physiotherapy had been recognized in healthcare. The emergence of physiotherapy, in the beginning as the separate health-care calling, later as the profession in the world, is related to the beginning of formal education. The first secondary school was founded in New Zealand as a school for the massage, today its the School for the Physiotherapy of the University in Otago. That school is thought of as the beginning of the formal education of physiotherapists in New Zealand. In 1918, in the USA, the education for "reconstruction aides" started, which marked the precursors of physiotherapists according to the researchers of the American Physiotherapy

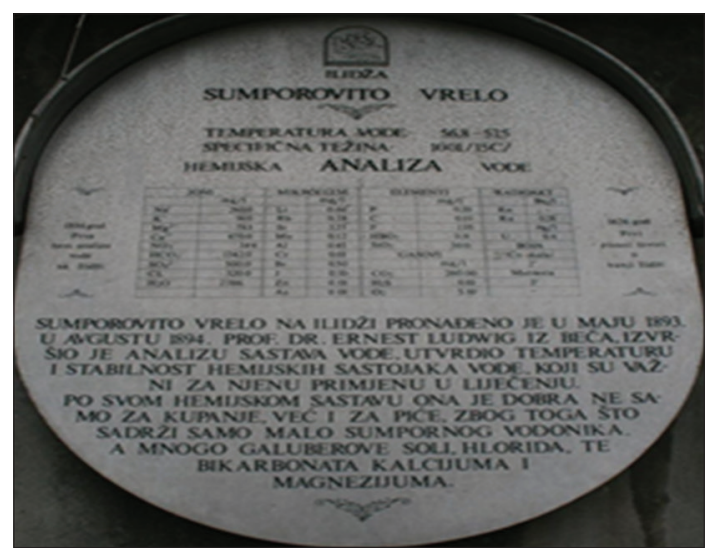

FIGURE 2. The first chemical analysis of water on lidža. Available at: https:/hoteliilidza.ba/bs/banja. 
history. The first university studies in physiotherapy started in 1938 in Australia (1).

For the development of physiotherapy and rehabilitation in $\mathrm{BiH}$, the event of great importance was coming of the expert of the World Health Organization professor Henry Kessler, PhD, a director of the Institute for Rehabilitation, Bellevue Medical Center, in New York, the first president of the Commission for the rehabilitation of the Social - Economic Council of UN then (1952). Professor Kessler held the prominent lecturer on the Faculty of Medicine in Sarajevo about his experiences in applying the physical therapy in rehabilitation of the patients, as well as its confirmed success and effective impact. Also in his lecture, as well as in his conversations with the representatives of the authorities of that period, especially from the Ministry of health and social politics, he emphasized the need for the education of personnel, where he mentioned physiotherapists as the important members of the rehabilitation team for the complete realization of the rehabilitation program. Something that contributed to the development of physiotherapy, as well as its recognizability in $\mathrm{BiH}$ was the visit by other great specialist and expert in the field of rehabilitation in USA professor Howard Rusk, PhD. Prof. Rusk has put the foundation stone for the building of some rehabilitation institutions where physical therapy was conducted. For the first time then in $\mathrm{BiH}$ Hubbard tank with underwater massage appeared, along with first modern "Swedish" ladders, parallel walking bars, various Zander devices from the field of mechanotherapy, devices from the field of the thermotherapy, as well as various means and tools for medical gymnastics (3).

\section{THE DEVELOPMENT OF PHYSIOTHERAPYIN BIH AS A HEALTH-CARE DISCIPLINE}

In the past few decades, physiotherapy has been developed as a significant health-care discipline that in treatment and rehabilitation of the injured and diseased has used a modern method of physical therapy.

The development of rehabilitation service in $\mathrm{BiH}$ in the period of $60 \mathrm{~s}$ was marked by consolidation of existing institutions with the experience and tradition in the treatment and using of thermomineral waters, preparing the personnel and providing the conditions for the opening and beginning of the activities in the most modern way according to the principles of modern medical rehabilitation, that were made by World Health Organization (9). In those years, physiotherapy was conducted exclusively in specialized ward of particular hospitals and clinics, institutionally in specialized health-care institutions and spa-climatic sanatoriums, often as the continuation of the begun hospital treatment. It is important to emphasize the role of the academic professor Mark Ciglar, $\mathrm{PhD}$, regular professor of physiatry and rehabilitation on Faculty of Medicine in Sarajevo, as the founder of the contemporary Institute for Physical Therapy on Ilidža in Sarajevo, that got the name institute for physiatry and rehabilitation in 1967 (Figure 3) (3,8). For the conducting of physical therapy and rehabilitation, the institute was equipped with rooms for kinesitherapy, electrotherapy, hydrotherapy, working therapy, and $\mathrm{x}$-ray and electromyography rooms and workshops for making orthosis. He owned the library that was equipped with professional literature and magazines and was one of the most equipped libraries in the Balkans.

Professor Ciglar, as the leader of the institute for physiatry and rehabilitation, gave the maximal support to his personnel, especially to the physiotherapists, in the education within their branch of profession and through different aspects of education, seminars and courses, within the country and outside of its borders. The physiotherapists actively participated in the researches, wrote professional studies and publicly presented them on the professional meetings. In those years, the Association

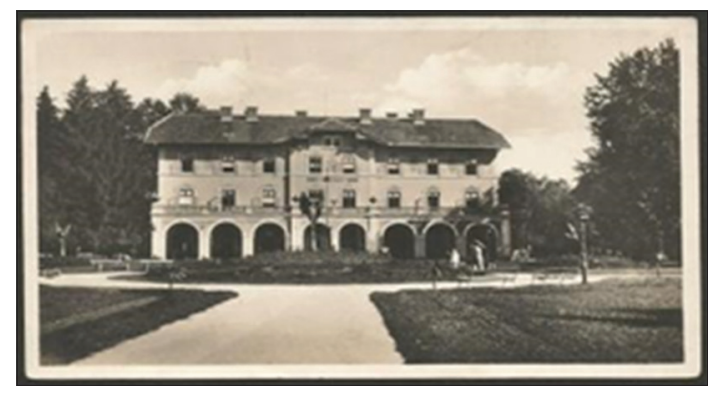

FIGURE 3. Spa "llidža" Sarajevo. Available at: https://www.kolekcionar.net/index.php?category=543\&start=60\&limit $=30$. 
of physiotherapists was established on the level of that period country, within which the Association of physiotherapists of $\mathrm{BiH}$ existed all until 1991.

The development of physiotherapy in the other cities in $\mathrm{BiH}$, in the seventies, has also experienced the ascent. Beside the institute for physiatry and rehabilitation Ilidža-Sarajevo, that was engaged in professional, educative and scientific research aspects, physiotherapy has equally successfully developed in other institutions all over $\mathrm{BiH}$ such as: the Institute for medical rehabilitation Banja Luka (the oldest institute in $\mathrm{BiH}$ ), the Clinics for rehabilitation and physical medicine Tuzla, the Institute for physical medicine and rehabilitation Mostar, the Institute for medical rehabilitation Fojnica, the Special hospital for cardiovascular diseases Teslić, the Special hospital for bone diseases Stolac, the Ward for medical rehabilitation of rheumatologic diseases Gradačac, the Ward for medical rehabilitation of gastrointestinal diseases Kiseljak, the Ward for medical rehabilitation Regional MC Foča, the Ward for medical rehabilitation Regional MC Travnik, and other services for physical medicine and rehabilitation of regional medical centers all over $\mathrm{BiH}$ (10). Beside these institutions the patients were also treated in sixteen spa-climatic sanatoriums that discreetly worked until that period, but they became new modern institutions with qualified personnel. According to the tradition and great trust in efficacy of thermomineral waters, spa-climatic sanatoriums have become the component of the rehabilitation system with the emphasis on physiotherapy with clearly determined indications and the way of applying the natural healing factors. Those are: Spa "Aquaterm" Olovo, Spa "Dvorovi” Bijeljina, Spa "Gata” Bihać, Spa "Guber” Srebrenica, Spa "Ilidža” Gradačac, Spa "Ilidža” near Sarajevo, Spa "Ilidža”" Sanski Most, Spa "Kiseljak" Kiseljak near Sarajevo, Spa "Kulaši”" Prnjavor, Spa "Laktaši” Laktaši, Spa "Mlječanica" Bosanska Dubica, Spa "Reumal" Fojnica, Spa "Slana Banja” Tuzla, Spa "Slatina” Banja Luka, Spa "Vilina Vlas" Višegrad, Spa "Vrućica” Teslić (11).

In the 80 s, the significant progress occurred in the development of physiotherapy all over $\mathrm{BiH}$, as well as the increased number of educated physiotherapists. There were 99 physiotherapists with high school professional education, and 112 with secondary school professional education that conducted physiotherapy on the specialist wards of particular hospitals and clinics, institutionally in specialized healthcare institutions and spa-climatic sanatoriums (10). During those years in $\mathrm{BiH}$ first ambulance - polyclinic and ambulance services of physical medicine and rehabilitation were organized at all rehabilitation medical centers, in whose teams there were also physiotherapists (10). Since 1986 the real prosperity of physiotherapy has begun in $\mathrm{BiH}$, where it was permanently worked on the advancing the services and the quality of workers knowledge (5).

Unfortunately, the continuity of physiotherapy in $\mathrm{BiH}$ was interrupted in 1992 by the beginning of war. During the war activities rehabilitation resources were considerably changed. The healthcare institutions were considerably damaged, as well as the equipment in them, and the significant reduction of healthcare professionals occurred (12). Among the first institutions that were damaged, the Institute for physical medicine and rehabilitation on Ilidža - Sarajevo was devastated and destroyed and it was the base for practice activities to the students of High medical school - department of physiotherapy.

In such situation, concerning the great number of wounded and hurt people there was an attempt to provide the physiotherapy care, sometimes in improvised conditions. During 1994 the conditions were considerably improved, with the help of the new equipment that could be used in war conditions without the electricity, received in the donation of government of Canada, WHO and NGO. After the peace was established the activities in restitution of the new concept of rehabilitation with the dispersity of services has followed all over $\mathrm{BiH}$. In that way on the territory of $\mathrm{BiH}, 62$ centers for physical therapy - CBR (Community Based Rehabilitation) centers were built and equipped through international projects, and then the program for the education of professionals followed in these centers, including physiotherapists (12).

Educative seminars were conducted on priority themes from rehabilitation: mental health, rehabilitation in the community, pain treatment, spine injuries, nervous system injuries, rehabilitation of children etc. Eminent professionals participated as educators, experts from Queen's university in Canada, WHO, HOPE PROJECT, SIDA SWEDEN, IRC, as well as many other international 
and local experts. Education was conducted in all the cities where there were CBR centers in duration of 2 years. Continuous seminar program was supervised by teams of physiotherapists experienced in the work with the sick persons in newly opened CBR - centers. The new work model in CBR centers enabled the employment of 266 persons, $52 \%$ of physiotherapists out of it $(13,14)$.

Introducing the new concept of rehabilitation organization, through the adequate space, modern equipment and educated personnel, the improvement in the conditions in the field of rehabilitation and physical therapy occurred, as well as the increase in the personnel of all profiles. Until $1992 \mathrm{in} \mathrm{BiH}$ 376 physiotherapists were employed, and immediately after the war the number of employed physiotherapists was 537. The new concept enabled the approach of the physiotherapy services to the far bigger number of users that radically changed the model of rehabilitation organization from the prewar - institutional to ambulance model on the level of the primary healthcare (12).

\section{THE DEVELOPMENT OF PHYSIOTHERAPY AS AN ACADEMIC DISCIPLINE}

Nowadays physiotherapy is manifested as an academic discipline that uses two approaches (paradigms) in studying (researching) problems based on Aristotle and Galileo's philosophical outcome. Physiotherapy science evolved from several scientific branches and it was positioned in scientific area of biomedicine and healthcare as the branch within the new interdisciplinary field of biomedical science and healthcare (15).

During the middle of the last century in $\mathrm{BiH}$ there were no schools that educated physiotherapists. For the qualifying, that is educating, the first personnel in rehabilitation, primarily physiotherapists and working therapists, the institutions out of $\mathrm{BiH}$ were responsible.

For long period of years The Federal institute for rehabilitation in Belgrade, headed by primarius Miroslav Zotović, was the main institution for the education of physiotherapists. The education lasted for 6 months till a year, and then the attendants went back to their institutions with the diploma of physiotherapist. All the attendants that went to professional qualifications, that is education, had to have at least finished medical secondary school, and some even more, the high school. Among the first qualified persons that conducted physiotherapy services, especially manual massage, were persons with poor vision and blind persons, educated in the Special schools for blind and persons with poor vision in Belgrade and Zemun. Great merit goes to professor Bogdan Brecelj, $\mathrm{PhD}$, the chief of the Orthopedic clinics, the founder of rehabilitation in Slovenia and to professor Đuro Sušec, $\mathrm{PhD}$, from Croatia that selflessly provided their help in the development of physiotherapy and rehabilitation in $\mathrm{BiH}$ (3). Due to the great number of institutions that engaged in physical therapy and rehabilitation, there was a need for the greater number of physiotherapy personnel, therefore for the opening the department of physiotherapy in medical secondary schools on the territory of $\mathrm{BiH}$ (16). In that period many students finished The Medical secondary school - department of physiotherapy in Banja Luka that in 1961 enrolled the first generation of physiotherapists as the first in $\mathrm{BiH}$. For the higher level of education students went to High medical school in Ljubljana that has dated since 1947 and to Belgrade to High medical school that opened the department of physiotherapy in the duration of 2 years in 1964. At the same time at the Higher medical school in Sarajevo, that by the Decision of the Council of the Faculty of medicine was founded in 1973, due to the expressed need for the establishing the department of physiotherapy technicians in 1977 , the study was done that got the approval of teaching scientific collegiate body and council of the Higher medical school. In that period the conditions allowed that comparatively to the request for the requirement of approval it could be begun with the admission and work, in that way one generation of physiotherapy technicians graduated. The first graduated physiotherapist in $\mathrm{BiH}$ that was educated at Higher medical school in Sarajevo was Ćemalović Belkisa, who graduated on January the $23^{\text {rd }}$, in 1979 . The government approval for opening the department for higher physiotherapy technicians, the Higher medical school in Sarajevo got in 1982, which is the year of the official beginning of work of the department for higher physiotherapy technicians in the duration of 2 years $(7,17)$. The students have attended all the 
lectures on Faculty of medicine, and the practice was done in the Clinical center and the institute for physiatry and rehabilitation - Ilidža Sarajevo. The higher medical school in Sarajevo has enabled the regular studying and studying along with the work that made the studying much easier for many students who were employed (17).

In the 80 s, the implementing of the Department of Physiotherapy in Medical Secondary Schools occurred in Sarajevo (1986), Mostar and Fojnica $(10,16)$.

Following the educational system of the developed countries of Europe and America, and before all the recommendations of the World Health Organization, with the aim of better education and coming closer to European educational space in 1990 the higher medical school in Sarajevo has introduced the 3-year studying with certain changes, additions, and innovations in its curriculum and syllabus (18).

During the war in $\mathrm{BiH}$, the work at the high medical school in Sarajevo, as the only one during that period in $\mathrm{BiH}$ that educated the higher physiotherapy personnel did not stop, but kept proceeding in the special conditions. The dean's office together with the teaching scientific council composed the curriculum and syllabus for the war conditions that were adopted and approved by the government, by which the lectures were performed all the time till the end of the war in the school year 1995/1996. The number of registered students during the war in $\mathrm{BiH}$ was considerably less, around $50 \%$ compared to the prewar period, and only $10 \%$ students graduated compared to the prewar period (17).

Immediately after the end of the war in $\mathrm{BiH}$, the staff from Queen's university worked with the professors on University in Sarajevo, on the improvement of the lecture quality for the physiotherapists, and in this way, a 1-year education for occupational therapists at the higher medical school of University of Sarajevo was organized (19).

In the postwar period in $\mathrm{BiH}$, the education of physiotherapy in secondary, higher, and high schools was conducted. The secondary school education of physiotherapists is still the conducted aspect of education that is realized through the 4-year education in the secondary schools in Sarajevo, Banja Luka, Mostar,
Fojnica, Trebinje, Tuzla, Travnik, Bihać, Zenica, Prijedor, Gradačac, Doboj, Bijeljina, and Bihać. The admission of students is performed every year, and in some schools, every $3^{\text {rd }}$ or $4^{\text {th }}$ years, depending on the needs for physiotherapy personnel, and to avoid the hyperproduction of personnel. After the finished secondary school, the department of physiotherapy, the students are enabled to continue their studying on former high medical schools, nowadays high medical school, that is, the faculties of health studies that educate the physiotherapists.

Higher medical school in Sarajevo with the longest tradition of existence on the territory of $\mathrm{BiH}$ in 1999 was renamed into high medical school, and in the academic year 2002/2003, it has enrolled the first generation of the physiotherapists for 4-year studying, who after the end of the study has gotten the title graduated physiotherapist (18). In 2008, high medical school was transferred into the Faculty of Health Studies, and in 2009, it has gotten the consent from the university for the conducting the Bologna study program (all three cycles). In the same year, the Faculty of Health Studies in Sarajevo got the approval of its curriculum and syllabus for the postgraduate study thus enabling the graduate students that finished their studying by the pre-Bologna system to acquire the title master of health studies from the field of kinesiology, kinesitherapy, and rehabilitation. Furthermore, for the candidates who finished their studies by the pre-Bologna education system in 2013, the procedure for acquiring the scientific degree of $\mathrm{PhD}$ in health studies was initiated. In 2015, BiH got its first $\mathrm{PhDs}$ in health studies who became the lecturers on the studies of physical therapy on the Faculty of Health Studies in Sarajevo (20).

In July 1997, higher medical school in Prijedor was opened which educated the physiotherapists, and since the school year 2007/2008 higher medical school in Prijedor has continued its work as high medical school which in its methodology of education curriculum has established the Bologna study metrics and introduced the 3-year studying. With time in higher medical school in Prijedor, there has been a need for establishing the 4-year study program. After the finished studies, the title medical graduate specialist in physiotherapy has been acquired (21). 
In Mostar, high health school was opened in 2000, and in May 2008, it changed its name to the Faculty of Health Studies, that is, a part of the University of Mostar. On the faculty, the university pregraduate lectures were performed where in the end of the studies the title bachelor (baccalaureus) of physiotherapy has been acquired. In 2008/2009, the university graduated studies were introduced - the masters studies in clinical physiotherapy where the title the master in physiotherapy has been acquired. Since the academic year, 2016/2017, Faculty of Health Studies has presented after graduate $\mathrm{PhD}$ studies in health studies (22).

In Banja Luka in 2007, the Faculty of Health Studies was opened on the private Paneuropean University "Apeiron," and in 2008, Faculty of Health Studies was opened in Travnik within the University "Vitez." Both of these private faculties have educated the physiotherapists on the studies of physiotherapy and working therapy where studying programs were coordinated to the Bologna process $(23,24)$.

Since 2009 at the Faculty of Medicine at University in Tuzla, the study of physiotherapy has been opened in 4-year duration where the title of graduate physiotherapist has been acquired and at the end of the second cycle, the title of master in physiotherapy (25).

Institutional manifestations of physiotherapy science have been present in an increasing number of countries through the organization of postgraduate doctorate studies in physiotherapy science. The aims of doctorate studies have been training the physiotherapists for critical thinking and independent research to increase the corpus of knowledge in physiotherapy science (15).

\section{CONCLUSION}

Historically speaking, it can be stated that in the field of physiotherapy as the health-care discipline in $\mathrm{BiH}$ the significant results were achieved in the development and education.

Compared to the prewar period, it can be noticed that the number of employed physiotherapists, as well as the number of institutions that educate the physiotherapists in the postwar period, has significantly been increased. The new possibilities for physiotherapists activities and working have been opened through the centers for the rehabilitation in the community (primary health care), hospitals, rehabilitation facilities, balneoclimatic rehabilitation centers, activities in house conditions, private centers, sports-recreational centers, as well as in the centers for the research and education.

The physiotherapists are no longer limited only to symptomatic treatment with physical agents, they have already become competent enough to carry out the physiotherapy process on their own (assessment, measuring, making the intervention plan, and evaluation), and to carry out the prevention programs to preserve and improve the health and the quality of life.

It is important to emphasize that due to the insufficiently systematized documentation from the prewar period, and especially after the break of the united institutions after the war that secured the development of physiotherapy in $\mathrm{BiH}$, it is very difficult to come to exact and checked data on the development of physiotherapy in $\mathrm{BiH}$. A great number of books, magazines, and libraries that contained the literature on physiotherapy was burned during the war and we were forced to collect the data from the doctors, physiotherapists, and other professionals who had been employed in the institutions that conducted the physical therapy to give us the oral data on the development of physiotherapy of that period.

\section{ACKNOWLEDGMENTS}

We are very thankful to Prim. dr. Željko Mišanović, Prim. dr. Mirha Begić, Enisa Pavlović, Muhamed Pašalić and Biljana Pandić for their unselfish help in writing this article.

\section{REFERENCES}

1. Jurinić A. Povijest fizioterapije u Hrvatskoj Fizioinfo. FIZIOinfo 2007;2:7-15

2. Đerković B. Geometralni Potencijali llidže, Sarajevo; 1987.

3. Kapetanović H, Pecar DŽ. Vodič u Rehabilitaciju. IP Svjetlost, Sarajevo; 2005.

4. Stanojević V. Istorija Medicine Medicinska Knjiga. Beograd, Zagreb: Medicinsko Izdavačko Preduzeće; 1953.

5. Avdović J, Dujmović M. Fizioterapija u BiH Kroz Istoriju. Istorija na Fizioterapija. Združenie na Profesionalni Fizioterapevti na Republika Makedonija, No. 6; 2013.

6. Mašić I. Zdravstvo u Bosni i Hercegovini Tokom Osmanskog Perioda. Avicena, Sarajevo; 1994. 
7. Mašić I. Korijeni Medicine i Zdravstva u Bosni i Hercegovini. Avicena, Sarajevo; 2004.

8. Vavra-Hadžiahmetović N, Bećirović E. Značaj Sumporne Vode za Programe Rehabilitacije. Prvi Balneološko-Turistički Internacionalni Simpozijum u Bosni i Hercegovini. Zbornik Radova, Kulaši; 2012.

9. Ciglar M. Rehabilitacija u Jugoslaviji i Njena Dostignuća, Smjernice Razvoja i Važnost za Društvo Zbornik Radova. Treći Kongres Ljekara za Fizikalnu Medicinu i Rehabilitaciju Jugoslavije. Sarajevo-llidža; 1979.

10. Pecar DŽ, Čorović N, Mišanović Ž. Stanje i Perspektiva Razvoja Fizikalne Medicine i Rehabilitacije. Zbornik Radova, Društvo Ljekara. Treći Kongres Ljekara BiH; 1985.

11. Bećirović E. Banjsko Klimatska Mjesta i Mineralne Stolne Vode Bosne i Hercegovine, Printcom, Tuzla; 2004.

12. Pecar DŽ. Rehabilitacija u Zajednici u Bosni i Hercegovini. Zbornik Radova Drugi Kongres Ljekara za Fizikalnu Medicinu i Rehabilitaciju Bosne i Hercegovine, sa Međunarodnim Učešćem. Fojnica, Novembar; 2007. p. 23-24.

13. Bećirović E. Program Rehabilitacije Žrtava Rata u Bosni i Hercegovini. Model Uspješne Implementacije CBR-Sistema. Zbornik Sažetaka. Drugi Hrvatski Kongres Fizikalne Medicine i Rehabilitacije. Varaždinske Toplice; 2000. p. 165-6.

14. Muftić M. Rehabilitacija u Zajednici. Iskustva i Budućnost. Projekat Rehabilitacije Žrtava Rata u Bosni i Hercegovini. Queens University, Referati sa Konferencije, Sarajevo; 1999.

15. Jurinić A, Filipec M. Filozofijske pretpostavke i epistemološki temelji teorije fizioterapijske znanosti. Physiother Croat 2016;14(Suppl 1):7-15.
16. Srednja Medicinska Škola Jezero. Available from: http://www.smsjezero. edu.ba/index.php/o-nama/historijat.

17. Čustović-Begović F, Mašić I, Mujić M. Almanah 1973-1998 Viša Medicinska Škola Sarajevo. Univerzitet u Sarajevu. Avicena, D.O.O., Sarajevo; 1998.

18. Visoka Zdravstvena Škola. Univezitet u Sarajevu. Jučer-danas-sutra. Focus Medical, Sarajevo; 2003.

19. Jaganjac N. Rehabilitacija u Zajednici. Iskustva i Budućnost. Projekat Rehabilitacije Žrtava Rata u Bosni i Hercegovini. Queens University, Referati sa Konferencije, Sarajevo; 1999.

20. Hadžiomerović AM, Pašalić A, Branković $S$, Jaganjac A. Obrazovanje Zdravstvenih Profesija u Novoj Epohi. $1^{\text {st }}$ Međunarodna Konferencija Zdravstvenih Profila I, $15^{\text {th }}$ Međunarodna Konferencija Medicinskih Sestara i Tehničara, Opatija; 2016.

21. Visoka Medicinska Škola Prijedor. Available from: http://www.vmspd.com. [Last accessed on 2018 apr 28]

22. Fakultet Zdravstvenih Studija. Sveučilište u Mostaru. Available from: http:// www.sve-mo.ba/fzs/index. [Last accessed on 2018 apr 28]

23. Panevropski Univerzitet, Apeiron Banja Luka. Fizioterapija i Radna Terapija. Available from: http://www.apeiron-uni.eu. https://doi.org/10.7251/ vje1401130s. [Last accessed on 2018 apr 30]

24. Fizioterapija i Radna Terapija. Sveučilište/Univerzitet Vitez. Available from: http://www.unvi.edu.ba.[Last accessed on 2018 may 03]

25. Medicinski Fakultet. Univerziteta u Sarajevu. Odsjek Zdravstvenih Studija. Available from: http://www.medf.untz.ba.[Last accessed on 2018 may 03] 